Bachman | Pedersen Zari | Enright | Lyn : Dulaney | Neveu

Kim | Bachman | Fisher : Hayes : Feldman: Grondzik

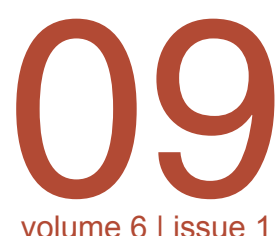

volume 6 | issue 1

\section{Designing student learning outcomes in undergraduate architecture education: Frameworks for assessment}

\author{
Leonard Bachman, The University of Houston-Central \\ Christine Bachman, The University of Houston-Downtown
}

the Higher Education Commission how it empirically institutionalizes reflection and refinement.

Coupled with these accreditation reporting requirements are some fundamental shifts in higher education, such as student-centered learning, active learning, and evidence based learning. Furthermore, increased use of the classroom itself as a laboratory for teaching and learning has begun to promote empirical insight and refinement. The Carnegie Academy for the Scholarship of Teaching and Learning (SOTL) is a prime example of this later development.

Over the past decade, the assessment of student learning has become increasingly important and the assessment literature suggests that direct evidence of student learning is a measure of institutional excellence (Bresciani, Zelna \& Anderson, 2004; Millersville University Assessment and Planning). As stated earlier, pressure from state accrediting agencies and the public sector continue to encourage institutions to enhance student learning. Given this mounting pressure for accountability and transparency, faculty and their institutions can no longer depend on anecdotal or self-validated evidence of student learning. Institutions must demonstrate evidence of student learning suggesting the dire need for creating measurable program learning outcomes. The specific situation of architecture schools is discussed here in this context.

\section{Embracing the culture of assessment and continuous introspection}

Assessment and accountability are here to stay. In the U.S., the Spellings Commission report called for a "robust culture of accountability and transparency." Similarly, proceedings from major conferences focusing on SOTL and assessment (Carnegie Academy for the SoTL; Texas A\&M, 2009 Assessment Conference) indicate that accountability and assessment are a worldwide phenomenon. The specific question here is-how do we assess the quality of architectural education in ways that facilitate the refinement of learning outcomes? For many educators of course, the "specter of standardized testing and a one-size-fits-all" approach is threatening (Shulman, 2007).

Accountability and evidence: The proactive perspective on accountability and assessment of student learning places the focus on program 
revitalization, organizational transformation and changing accreditation processes (Ratcliff, Lubinescu and Gaffney, 2001, p 5). During the 1990s, assessment and accountability were primarily defined as "the systematic collection of input, process and outcome data, as well as the use of these data to make decisions about the effectiveness of schools" (Education Commission of the States). Today, changes in assessment focus on learning outcome measures, direct measures, program assessment, student learning and program responsibility rather than on institutional effectiveness (Rogers, 2009). Based on current literature (Angelo, 1995), assessment requires

- setting explicit and expectations and making them public to all stakeholders,

- establishing appropriate criteria and standards for learning quality,

- systematic collection of empirical data as both direct and indirect evidence,

- analyzing and interpreting evidence to identify how well student performance corresponds with expectations and standards, and finally

- using results to document, explain and improve performance, teaching and student learning.

As the assessment process is an on-going activity designed to increase the mission of each program discipline and department, the process is dynamic and is both dialectic and long term (Fig 1). Recent assessment evidence emphasizes the need for identifying specific and measurable

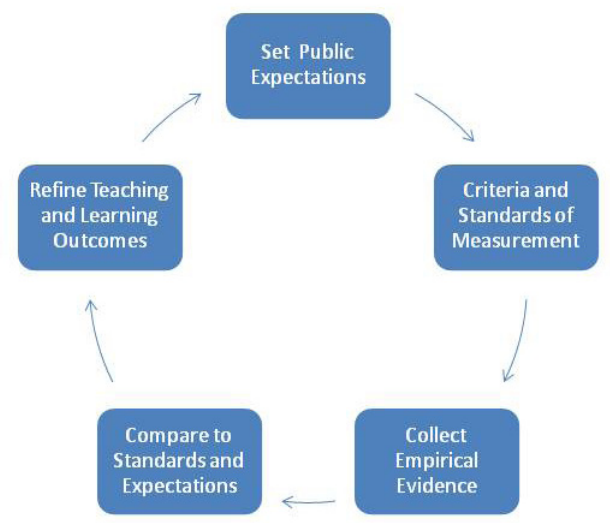

Figure 1: Closing the loop with assessment

learning outcomes to create opportunities to enhance program coherence and our ability to plan for the future (Texas A\&M Conference, 2009.) Program coherence can be used to help students understand what is expected of them and promote learning. Assessment results contribute to planning by promoting further examination of curricular activities and helping in making adjustments or revisions of the curriculum.

What is a measurable learning outcome? First let us discuss the terms used in describing elements of a curriculum. The convention used in this paper follows a typical planning model which is based on a rough hierarchy of mission, values, goals, objectives and outcomes, tactics, and strategy. Each of those terms is used in the later parts of this paper to outline a model framework for architectural education. At this stage however, learning outcomes can be thought of in a couple different ways. At the program level a learning outcome is much like a goal, an ultimate destination. Higher Education commissions now require that each program defines a small number of such program outcomes as the end result of a graduating student's cumulative educational experience. At the course level however, learning outcomes are more like planning model objectives. Such objectives are measureable in ways that are not open to interpretation, and are used to scale success or failure and to set thresholds to operationalize the objective as met or unmet in defensibly empirical ways. Normally a course has many learning objectives and all student learning activities are targeted at one or more specific objectives. Program level learning outcomes are, on the other hand, more globally assessed through supporting but less scalable evidence. Somewhere in between are the NAAB Student Performance Criteria (SPC) which describe course outcomes that can be identified among evidence from specific courses. The SPC are thus larger scale than course learning objectives and smaller than program learning outcomes. At this point of the discussion, a "learning outcome" referring to any one of the three scales is essentially synonymous with "learning objective."

For more on this terminology, Bresciani $(2001 ; 2007)$ lists essential components in creating measurable and meaningful outcomes: The key element is to operationalize student learning. In other words, what are architecture students expected to learn and how can that learning be empirically measured? Bresciani (2007) differentiates between program outcomes (i.e., architecture program achievement), learning outcomes (student learning as a result of the curriculum) and developmental outcomes (students' feelings and attitudes about their education). In architecture, Watt and Cottrell (2006) define learning outcomes as a "set of competences including knowledge, understanding and skills that a learner is expected to know/understand/demonstrate after completion of a process of learning - short or long." They further discuss learning outcomes as a point of reference for curriculum design and evaluation and how such outcomes should allow flexibility and autonomy in developing curricula. Mostly, they believe that learning outcomes provide a "common language for describing what curricula are aiming at."

Recently, the American Institute of Architects education web site published a page on "Learning Objectives: What are they and how do I write one?" (AIA, 2009). This resource defines learning objectives as "an explicit statement that clearly expresses what the student will learn or be able to do after taking the course... an observable and measureable 
student outcome statement... open to limited interpretation" and further states that "a learning objective is where the design and development of an educational program begins." It goes on to promote three elements of a learning objective as the behavior (activity leading to what participants will gain in ability), the condition (constraints under which the behavior is framed), and the criteria (how student performance is evaluated). Finally, this overview resource advocates the use of Bloom's taxonomy of educational objectives (see Bloom, 1956). Ample evidence indicates that using the Bloom's taxonomy or derivative works to design meaningful learning outcomes results in better assessment methods. Recent revisions to the taxonomy includes more outcome-oriented language, workable objectives and active verbs, and helps distinguish the different levels of cognition on a scale from remembering to applying, analyzing, evaluating, and creating (Anderson and Krathwohl, 2001).

An illustration of this adapted taxonomy along with corresponding action keywords from the Bloom taxonomy is shown in Figure 2. The Bloom's action verbs can be used to connect all areas of the curriculum and to accommodate measurement and assessment. For instance, verbs such as

- remembering is used to assess retrieval, recalling and recognizing. At this basic level, assessment measures students' ability to recall and recognize information, ideas and principles.

- understanding is used to construct meaning from different types of knowledge, either written or graphic. At this level, assessment is more sophisticated and examines students' ability to interpret, classify knowledge, infer, compare and explain the concepts and material covered in a specific course and/or in prior courses.

- applying is used to perform a process through the execution of implementation. At this level, assessment focuses on students' ability to apply information, ideas and principles students have learned in various courses through products such as research papers, models, presentations, drawings or simulations.

- analyzing is used to compare and contrast, classify and link assumptions, hypotheses, evidence or structure information, ideas and principles. At this stage, students are assessed on their ability to dissect the concepts or material they learn and to organize them in new ways such as writing research papers or creating spreadsheets, diagrams or drawings.

- evaluating is used to examine students' abilities to systematically examine and critique information, ideas and principles. At this level, students are assessed on their ability to critique and make recommendations about new approaches using specific standards and criteria.
- creating is the last step in the taxonomy and indicates students capacity for reorganizing elements in new ways, planning and generating new ideas.

The Bloom's taxonomy and its recent revisions allow for each discipline to identify means of assessment, design appropriate instruments and produce reliable findings that can be applied toward reform in the curriculum or planning new teaching strategies.

Anderson and Krathwohl (2001) further describe the levels of cognitive process from remembering to creating as one axis in a larger matrix. Along the other axis they classify factual, conceptual, procedural, and metacognitive "knowledge dimensions." For the purposes of this paper however, we offer a more detailed set of classifications in Table 1. The body of the matrix formed by the axis of six cognitive processes and other axis of six knowledge dimensions forms a grid of 36 cells. Each of these cells is a potential coordinate for the design of a learning objective (Table 2). Finally, it is possible to unify these concepts in a map charting the areas of architectural curriculum (Table 3). In this final table the knowledge aspects of declarative domain knowledge, procedural technique, and structural wisdom are not mapped as levels of complexity as in Table 2, but rather to depict different frames of knowledge as just one of the many parallel concepts that tie the curriculum areas together in complimentary ways. Table 3 also lists a synthetic and holistic area of shared curriculum common to all the topic areas.

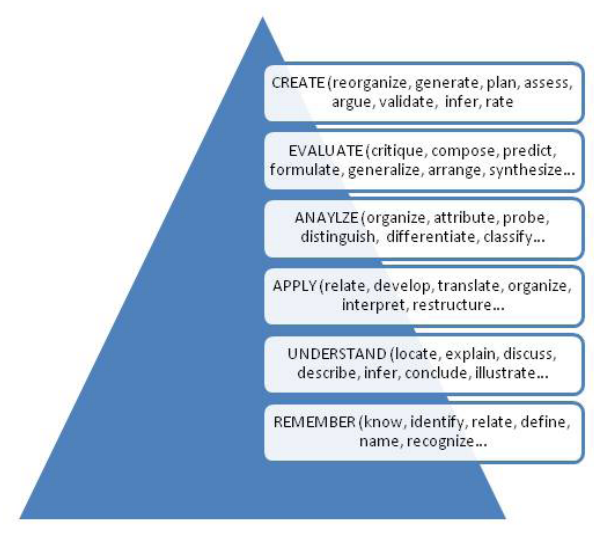

Figure 2: Bloom's taxonomy after a revision by Anderson and Krathwohl (2001) 
Table 1: Matrix of cognitive processes and knowledge dimensions.

\begin{tabular}{|c|c|c|c|c|c|c|}
\hline Level & Example & Transformation & Actor & Order & Context & \multirow{3}{*}{$\begin{array}{c}\text { Realm } \\
\text { Experience }\end{array}$} \\
\hline Facts & Current Temperature & Observation & Awareness & Tsolated & Explicit & \\
\hline Data & Average Daily Temperatures & Organization & Curiosity & Structured & Organized & \\
\hline Tnformation & Monthly Degree Days & Relation & Appreciation & Scaled & Analytical & \multirow[t]{2}{*}{ Concepts } \\
\hline Knowledge & Appropriate Passive Systems & Application & Tllumination & Connected & Tnterpretive & \\
\hline Understanding & Functional Integration & Tntegration & Expertise & Networked & Tmplicit & \multirow[t]{2}{*}{ Design } \\
\hline Wisdom & Systemic Integration & Theory & Virtuosity & Dynamic & Tacit, Zen & \\
\hline
\end{tabular}

Table 2: Matrix of thirty-six potential coordinates for learning objectives.

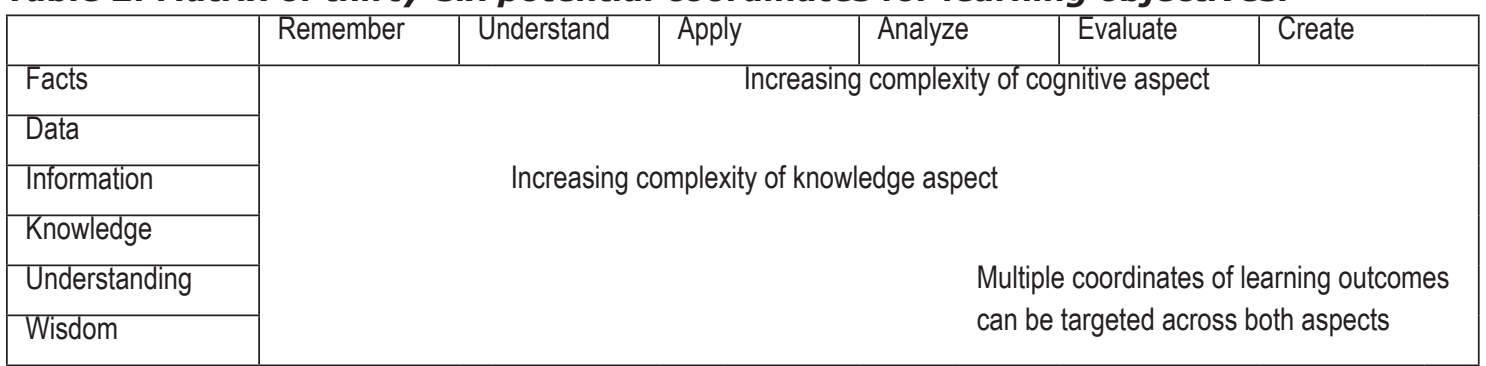

Table 3: The authors' proposed map for frames of knowledge in architectural education.

\begin{tabular}{|c|c|c|c|c|}
\hline & & Curriculum Are & & \\
\hline & Meaningful Experience & Analytical Evaluation & Design Decisions & Architectural Ideas \\
\hline & History Theory Criticism & Technology Programming Practice & Studio Courses & Shared Curriculum \\
\hline & Content (what) & Means (how) & Context (so that) & Ideals (why) \\
\hline & Substance & Sustenance & Passion & Significance \\
\hline & Inspiration & Insight & Judgment & Imagination \\
\hline & Precedent & Integration & Formalization & Connection \\
\hline \&े & Vocabulary & Tools and Protocols & Belief & Adductive Proposition \\
\hline ঠั & Engagement & Transformation & Risk and Courage & Assertion \\
\hline$\frac{\bar{\Phi}}{\bar{\sigma}}$ & Domain Knowledge & Procedural Knowledge & Critical & Structural Knowledge \\
\hline & Emplotment & Equilibrium & Manifestation & Innovation \\
\hline & Heritage & Society & Culture & Civilization \\
\hline & Knowledge & Work & Resolution & Expression \\
\hline & Values & Strategy & Satisfaction & Wisdom \\
\hline & Currency & Intelligence & Aesthetics & The Sublime \\
\hline
\end{tabular}




\section{Program outcomes and course objectives in architectural education}

The Associate Collegiate Schools of Architecture (ACSA) in concert with the National Architectural Accrediting Board (NAAB) and other collateral organizations recently formed an Accreditation Review task force to re-examine accrediting standards and Student Performance Criteria (SPC) for 2009. The mission was to revise the goals for SPC to be more explicit and hierarchical. An Accreditation Review Conference was held October 22-23, 2008 in Tucson, Arizona for fifty representatives from all the collateral organizations. The process eventually identified four core values: Design, Leadership, Stewardship, and Critical Thinking. This new approach places a greater emphasis on operationally defining goals and learning outcomes. Specifically, the NAAB indicates a need for learning outcomes specific to architecture education and for articulated strategies to address how those goals can be achieved. Each school of architecture is still given leeway to develop specific learning outcomes according to their specialization, tradition or resources (see,.Oklahoma State University, 2004; Petri, 2004; Spiridonidis, nd.; University of Western Australia, nd)

\section{Measures of creativity}

In a creative endeavor such as architecture, there is some inherent resistance to the idea of empirical measurement and doubt as to its relevancy. In fact however, creativity can be taught and learned. Like every other personal trait, some individuals may have more or less natural inclination to be creative, but all individuals can be taught to enhance their creative work and thinking. Since the architecture curriculum is designed to affect this teaching, the efficacy of the curriculum and the faculty can be evaluated. In the end, it is not the sublime qualities of architecture that assessment is geared to measure but the effectiveness of a particular program of instruction and the potential areas of refinement. The same principle applies to art, poetry, psychology, math and every other topic area. Clearly, no program of instruction has yet achieved perfection. The culture of assessment merely encourages reflection, introspection, and self-critique for all, and insists that the process be free of self-satisfying bias and conservative complacency.

What is creativity? Creativity itself is frequently believed to be "artistic, lofty, out-of-the ordinary and beyond understanding" (Dickhut, n.d.). Schools of architecture thus experience challenges "articulating criteria for evaluating creative work" (Mayo, 1991). However, the key in identifying what constitutes a creative person and creative work is in its definition? Clearly, creativity can be defined in several ways and at many distinct levels: cognitively, intellectually, socially, economically, spiritually, and from the finite perspective of different disciplines.

According to Sternberg (1985), three intellectual skills play an important role in enhancing creativity, all of which can be learned. First, the synthetic skill includes the ability to generate novel and interesting ideas and make spontaneous connections between ideas. The second skill refers to analytical approach which consists of convergent thinking and appraisal in considering implications for all possible responses, problems and outcomes. Lastly, the practical skill refers to one's ability to translate abstractions and theories into realistic applications. Such skill is important in communicating ideas and motivating others to consider those creative ideas. Therefore, creativity can be easily assessed as the fulfillment of these three skills. Similarly, others consider cognitive processes and structures that contribute to creative thinking and discovery (Finke, Ward and Smith, 1992). As such creativity is a product of numerous cognitive processes, each of which contributes to insight and discovery. These processes and principles of creative cognition can be applied across disciplines, including architecture. In this context, the assessment dialectic process of creativity directly benefits from using the Bloom's taxonomy as explained earlier.

Some distinctions in architectural discourse regarding assessment

\begin{abstract}
"a building has to start in the unmeasurable aura and go through the measurable to be accomplished. It is the only way you can build, the only way you can get it into being is through the measurable. You must follow the laws but in the end when the building becomes part of living it evokes unmeasurable qualities. Louis Kahn, "Form and Design", p. 149.
\end{abstract}

Architectural education, by necessity, grapples simultaneously with two different evaluation systems. On one hand are the sublime, ephemeral and immeasurable qualities of what constitutes architecture and on the other is the rigor of measured learning outcomes. This inherent duality suggests that there are pitfalls and "traps in architectural discourse" (Heath, 1991) where the differences are confused, conflated, or simply ignored. Such mistakes subvert real evaluation and assessment. The following is a beginning list of such pitfalls.

Quantitative and qualitative versus objective and subjective: Qualitative must not be confused with subjective. In fact the distinction of qualitative/ quantitative is quite separate from that of objective/subjective. The former relates to two means of empirical measure which use different but equally valid scales, while the latter differentiates opinion from fact or the subject in one's mind from the object itself in the world. The danger of crossover here is that the sublime interpretations of student's work would be substituted for empirical evaluation of their learning. In other words, the ephemeral notion of architectural design is declared immeasurable and therefore design learning is itself immune to empirical evaluation. Worse, the really fatal threat here is that design must remain property of the master: cloaked in talent, mystery, genius, and voodoo; in which case design cannot be taught and schools of architecture should probably 
disband. Instead, educators must embrace the idea that colleges are places of learning and that students are becoming architects. Students learn to understand their own activities and products, and how to evaluate their own work to make their efforts meaningful and their learning productive. In short, valid evaluation can be qualitative or quantitative, but the process of evaluation needs to be explicit and must relate to stated objectives by which students clearly know in advance how they are evaluated.

To elaborate a bit, quantitative measurement includes numerical data. The data can be analyzed using statistical methods and results can be illustrated using tables, charts, histograms and graphs. Qualitative measurements consist of data collected that is not numeric such as grading of written work using a rubric, results from group discussions, interviews, case study evaluations and artistic portfolios (Trochim, 2000). Evaluation of qualitative data often focuses on chunking the data based on themes. Such data can produce great insight in understanding a particular measurement. For instance, using a grading rubric can assist in evaluating student writing and a resulting value can be assigned based on standard criteria, or help devise a matrix to assess creativity. Finally, calculating frequency or percentage in each category allows for a better understanding of the results (Bailey, 1994).

Talent, creativity, genius and skill: Talent, creativity, and skill can all be taught and learned. Genius, on the other hand is probably best thought of as inherent predisposition, aptitude, or inclination. The entymological root of genius is, after all, the mythological Roman genii or the Muslem jinni. Such extracognitive ability may be earned by extreme effort, but it is hardly the barometer of normal teaching and learning. Albert Einstein, Sir Isaac Newton, Mozart, Le Corbusier, or Frank Lloyd Wright all epitomize creativity and ability beyond what we recognize as talent or skill. Talent, creativity, genius and skill have been examined extensively. Some examine what they call "extra cognitive aspects of high ability" to explain brilliant achievement and the elusive qualities held by certain individuals (Shavinina and Ferrari, 2005). Conversely Howe (2005) argues that it is work ethic, perseverance and interpersonal skills that are essential in developing "extracognition." Finally, Subotnik (2005) discusses the development of artists and focuses on Julliard's strategies and techniques used during the students' academic training.

The ultimate point here is, given that talent, creativity and skill can be nurtured and taught, then student learning can be assessed. A college student's journey in any discipline needs to be mapped to capture what strategies to use, and what learning to cover and omit (Harden, 2001). To impact student learning then, instructors must commit to using datadriven evidence rather than verbal claims.

Intuitive and counterintuitive vs. rational and imaginative: Contrary to popular belief, intuition is based on experience, and not only on imagination. Intuition involves direct insight that is independent of rational reasoning, but this only makes insight more of a heuristic shortcut or cognitive process of knee-jerk reaction rather than of reflection and consideration. Without prior experience in the matter, there is no background on which to base the shortcut. When we speak of intuition then, it is a mistake to equate it to what Coleridge meant by spontaneous imagination:

The primary [spontaneous] imagination I hold to be the living power and prime agent of all human perception... The secondary [contemplative imagination] I consider as an echo of the former, coexisting with the conscious will, yet still identical with the primary in the kind of its agency, and differing only in degree, and in the mode of its operation [dissolve, diffuse, idealize, dissipate, unify]... Fancy, on the contrary, has no other counters to play with, but [ready-made] fixities and definites. The fancy is indeed no other than a mode of memory. S. T. Coleridge, 1817.

Continuous vs. discrete measures: The distinction between calculating height and weight versus the headcount of males and females is between a continuous scale or variable and a discrete scale or variable. Counting the number males and females in attendance results in possible discrete numbers of 20 females and 30 males. It is impossible to tally 14.5 females. Conversely, calculating one's height and weight can easily be broken down in infinite numbers on a continuous scale. Student performance toward learning outcomes needs to be viewed as a continuous measure. Instructors convert continuous variables into discrete ones by dividing up the continuous variable into a range of values and then assign the same discrete value to all values of the continuous variable that fall within a certain range $(A, A-, B+$, etc.). Using continuous measures help faculty to easily rank students and evaluate their work using on a scale ranging from zero to 100.

Extrinsic versus intrinsic: Extrinsic behaviors refer to those actions resulting because of some reward while intrinsic behaviors are those that are performed because they are inherently enjoyable or otherwise performed for their own sake. Educators often emphasize extrinsic behaviors such that students who worked diligently are more likely to be rewarded with a good grade. In contrast, when students feel engaged and enjoy their learning experience, they will be more likely to be intrinsically motivated to learn.

Explicit versus implicit learning: Implicit learning is characterized as a passive process whereby individuals learn by exposure. This process of learning occurs naturally and unconsciously. Conversely, explicit learning is an active and conscious process that requires awareness of specific skills. Constructive feedback, a rubric, or a grade can be used to help student become more attentive of what they need to focus on.

Direct and indirect measures: Direct measures of learning are based on actual student performance and the artifacts of their learning activities. 
Student performance results as evidence only if it satisfies the initial intention, such as a stated learning outcome declared in a project assignment or in the course syllabus. Examples of direct measures are written assignments, classroom assignments, presentations, test results, research projects, logs, portfolios or e-folios, and direct observations (e.g., architectural critiques, review or juries) (Leskes, 2002). Indirect measures of learning are those that evaluate students' feelings and perceptions with regard to their learning experience and environment. Examples include surveys, exit interviews with graduating students, focus groups, and reflective essays (Eder, 2004).

Given these warnings and a better understanding of the various forms that may influence assessment, it is important to devise the best possible assessment measures. In addition, much of the measurement literature warns against "pursuing the blind alley of value added assessment" (Banta, 2007). As such there is no first order need to compare programs at various institutions as students differ in many ways. Instead, it is important to identify standardized assessment methods that provide meaningful information for a specific educational environment.

\section{Using the general planning and APA assessment models in Architecture education}

The model used in developing a framework for assessment of learning outcomes for architecture education was paralleled with the American Psychological Association (APA) Task Force. The APA psychology learning goals and outcomes express expectations for graduating seniors' performance regardless of resources, student or faculty characteristics. The APA Task Force developed goals and outcomes that address overarching goals, and assist psychology faculty and department in "curriculum design, goal setting and assessment planning" (APA guidelines) The APA model and the NAAB goals are used in the present document to prompt discourse among architecture faculty and to facilitate the assessment process. Recently, schools of architecture have been using learning outcomes and reporting assessment of learning, but there is very little literature available describing best practices regarding the development of program learning outcomes in architecture education. To facilitate the process, we used the APA model as well as the National Architecture Accreditation Board (NAAB) student performance criteria.

As currently defined by NAAB, student performance criteria are difficult to actually measure. However, the SPC used as qualitative standards allow great flexibility in how each school can fulfill the criteria within their own curriculum plan. Additionally, the SPC are only evaluated every five or six years at a given institution, and the process consists of a busy five-day review by a visiting team. The Visiting Team Report (VTR) is based on intersubjective agreement among the team members as to whether the host program satisfies the SPC as well as the many general conditions. In the end, the process has historically been well focused, but only applied intermittently and was based more on current success than on a continuous process of refinement and improvement. It is worth pointing out that the proposed 2009 NAAB Conditions reverse this trend. Part One is now titled "Institutional Support and Commitment to Continuous Improvement" and contains the following requirements of the Architectural Program Report (APR) that is prepared for accreditation:

The APR must include the following:

- A description of the process by which the program identifies its objectives for continuous improvement.

- A description of the data and information sources used to inform the development of these objectives.

- A description of the role of long-range planning in other programmatic and institutional planning initiatives.

- A description of the role the five perspectives play in long-range planning.

Developing goals and outcomes that can be applied broadly across schools of architectures is critical but not prescriptive. In this paper, we propose that specific program learning outcomes support high quality performance and facilitate assessment.

\section{A proposed model of learning outcomes in architectural education}

The typical general project planning model (Tables 4-7) begins with a mission that is aligned with a set of values, establishes goals that define the mission, and works down through objectives and tactics for achieving the goals... all wrapped into a set of strategies that make the plan coherent and the resources available. The following tables are meant to illustrate how that planning model is reflected in the APA assessment model, as well as how it meshes with NAAB SPC, and ultimately with a workable framework for assessing learning outcomes in any school of architecture. 


\section{Table 4. Mission and Values}

\begin{tabular}{|c|c|c|c|}
\hline $\begin{array}{l}\text { PLANNING } \\
\text { MODEL }\end{array}$ & CURRICULUM MODEL & NAAB (from NAAB 2009) & APA \\
\hline $\begin{array}{l}\text { Mission- reason } \\
\text { for existence of } \\
\text { the program }\end{array}$ & $\begin{array}{l}\text { - We strive to produce graduates who } \\
\text { question deeply and who are skilled in } \\
\text { their craft, who can utilize advanced } \\
\text { technology and advanced methods of } \\
\text { industrialized production, who understand } \\
\text { and respect the power of design to shape } \\
\text { our lives, and who are equipped to use } \\
\text { their design skills to be effective in the } \\
\text { world. (University of Houston) } \\
\text { - The Coll ege of Architecture educates } \\
\text { students for future design practice and } \\
\text { advances knowledge of the discipline for } \\
\text { the benefit of society. (Texas Tech } \\
\text { University) } \\
\text { - The BAC is committed to provide } \\
\text { excellence in design education grounded } \\
\text { in practice and accessible to diverse } \\
\text { communities. (Boston) } \\
\text { - Students will be educated to become } \\
\text { professional leaders and participants in } \\
\text { public life, helping to bring balance to the } \\
\text { often conflicting objectives of resource } \\
\text { stewardship and community development. } \\
\text { (Kansas State University) }\end{array}$ & $\begin{array}{l}\text { 1. provide support and } \\
\text { encouragement for students to } \\
\text { assume leadership roles in } \\
\text { school and later in the } \\
\text { profession } \\
\text { 2. provide students with a } \\
\text { sound preparation for the } \\
\text { transition to internship and } \\
\text { licensure } \\
\text { 3. prepare students to practice } \\
\text { and assume new roles and } \\
\text { responsibiliti es in a context of } \\
\text { increasing cultural diversity, } \\
\text { changing client and regulatory } \\
\text { demands, and an expanding } \\
\text { knowledge base } \\
\text { 4. equip students with an } \\
\text { informed understanding of } \\
\text { social and environmental } \\
\text { problems and develops their } \\
\text { capacity to address these } \\
\text { problems with sound } \\
\text { architecture and urban design } \\
\text { decisions }\end{array}$ & $\begin{array}{l}\text { 1. provides optimal expectations } \\
\text { of performance at the completion } \\
\text { of the baccalaureate degree } \\
\text { 2. promotes education that } \\
\text { focuses on knowledge, skills and } \\
\text { values that are consistent with } \\
\text { the science and application of the } \\
\text { discipline } \\
\text { 3. contributes tools to basic } \\
\text { knowledge (retention and } \\
\text { comprehension), development } \\
\text { (analysis and application), and } \\
\text { advanced (evaluation and } \\
\text { creating) } \\
\text { 4. advances the creation, } \\
\text { communication and application of } \\
\text { knowledge to benefit society and } \\
\text { improve peopl e's life } \\
\text { 5. prepare students for advanced } \\
\text { degrees (teaching or research) }\end{array}$ \\
\hline $\begin{array}{l}\text { Values- } \\
\text { fundamental and } \\
\text { shared basis of } \\
\text { reasoning, } \\
\text { critique, and } \\
\text { discourse }\end{array}$ & $\begin{array}{l}\text { Hypothetical, as proposed by the } \\
\text { authors: We believe that the quality and } \\
\text { vitality of the built environment is best } \\
\text { attained through the activity and } \\
\text { processes of architectural design. We } \\
\text { also hold that design is ultimately guided } \\
\text { by a quest to realize human aspiration as } \\
\text { well as to embody human intelligence } \\
\text { [hypothetical example by authors] }\end{array}$ & $\begin{array}{l}\text { From ACSA (2008) as adopted } \\
\text { from Boyer and Mitgang } \\
\text { 1996): } \\
\text { 1. that architectural education } \\
\text { programs should be guided by } \\
\text { diverse missions informed by an } \\
\text { understanding of architecture as } \\
\text { a profession that serves society; } \\
\text { 2. that professional programs } \\
\text { should be evaluated through } \\
\text { "standards without } \\
\text { standardization"; } \\
\text { 3. that students should learn in } \\
\text { a supportive climate. }\end{array}$ & $\begin{array}{l}\text { 1. promote knowledge base of } \\
\text { the discipline } \\
\text { 2. develop research and critical } \\
\text { thinking skills } \\
\text { 3. evaluate how the discipline } \\
\text { contributes to societal change } \\
\text { 4. apply knowledge of the } \\
\text { discipline to everyday life } \\
\text { 5. support the development of } \\
\text { values regarding ethical } \\
\text { principles, tolerance of ambiguity, } \\
\text { skepticism, curiosity, human } \\
\text { diversity, and fostering positive } \\
\text { civic, social and/or global } \\
\text { awareness. }\end{array}$ \\
\hline
\end{tabular}


Table 5. Goals

\begin{tabular}{|c|c|c|c|}
\hline $\begin{array}{l}\text { PLANNING } \\
\text { MODEL }\end{array}$ & CURRICULUM MODEL & NAAB & APA \\
\hline $\begin{array}{l}\text { Goals- highlights } \\
\text { of what you do, } \\
\text { what should be } \\
\text { gained from the } \\
\text { project }\end{array}$ & $\begin{array}{l}\text { Hypothetical as proposed by the } \\
\text { authors: } \\
\text { 1. HISTORY: Knowledge of the history } \\
\text { and theories of architecture as they relate } \\
\text { to design thinking, cultural aspiration, } \\
\text { social needs, and the evolution of the built } \\
\text { environment; including the discourse that } \\
\text { distinguishes critical works of architecture } \\
\text { from normatively satisfactory buildings } \\
\text { 2. PHYSICAL DESIGN: The ability to } \\
\text { articulate aesthetic viewpoints that } \\
\text { connect architectural ideals with practical } \\
\text { means of their realization in construction, } \\
\text { or otherwise stated, the ability to } \\
\text { formulate a clearly stated architectural } \\
\text { idea and translate it into graphic and } \\
\text { written proposals for realizing its practical } \\
\text { form and function (here I broadly mean } \\
\text { aesthetics as the philosophy of human } \\
\text { appreciation) } \\
\text { 3. PRACTICE: Knowledge of } \\
\text { collaborative design, information } \\
\text { technology, conventional and emerging } \\
\text { business models, construction operations, } \\
\text { and the ethical and legal responsibility of } \\
\text { architects, including service to society } \\
\text { and culture, public safety and welfare, } \\
\text { and contract law } \\
\text { 4. RESEARCH: The ability to evaluate } \\
\text { information, formulate significant } \\
\text { questions, critique exis ting knowledge, } \\
\text { utilize appropriate methods of inquiry, and } \\
\text { contribute new wisdom to the discipline of } \\
\text { architecture } \\
\text { 5. STRATEGIC DESIGN: The ability to } \\
\text { assess a building project and then } \\
\text { formulate a comprehensive program for } \\
\text { its design, construction, postoccupancy } \\
\text { evaluation, and continuous } \\
\text { commissioning }\end{array}$ & $\begin{array}{l}\text { NAAB (2009) labels these as } \\
\text { values, but they are in fact } \\
\text { goals that NAAB wishes for } \\
\text { programs to achieve } \\
\text { 1. Design architectural projects } \\
\text { with creativity and technical } \\
\text { mastery. } \\
\text { 2. Lead interdisciplinary design } \\
\text { projects ethically and } \\
\text { collaboratively. } \\
\text { 3. Be active stewards of the } \\
\text { environment. } \\
\text { 4. Think and act critically. } \\
\text { 5. Work in a nurturing, } \\
\text { engaging, and safe } \\
\text { environment. }\end{array}$ & $\begin{array}{l}\text { 1. Knowledge base: Be able to } \\
\text { demonstrate familiarity with the } \\
\text { major concepts, theories, } \\
\text { empirical findings and historical } \\
\text { trends } \\
\text { 2. Research methods: } \\
\text { Understand and apply basic } \\
\text { research methods including } \\
\text { research design, data collection } \\
\text { and analysis, and interpretation } \\
\text { 3. Critical thinking skills: Respect } \\
\text { and use critical and creative } \\
\text { thinking, skeptical inquiry, and, } \\
\text { the scientific approach to solve } \\
\text { problems related to behavior and } \\
\text { metal processes } \\
\text { 4. Application of theories and } \\
\text { values: Understand and apply } \\
\text { principles to personal, social and } \\
\text { organizational issues. Use } \\
\text { empirical evidence, tolerate } \\
\text { ambiguity, act ethically, and } \\
\text { reflect other values that are } \\
\text { pertinent to the science of the } \\
\text { discipline } \\
\text { 5. Information and technological } \\
\text { literacy: Demonstrate information } \\
\text { competence and the ability to use } \\
\text { computers and other technology } \\
\text { for many purposes } \\
\text { a. Effective communication skills. } \\
\text { processes and apply effective } \\
\text { awareness: Recognize, } \\
\text { understand and respects the } \\
\text { complexity of sociocultural and } \\
\text { international diversity } \\
\text { and Peronal development: } \\
\text { peright into their own } \\
\text { pehavior and mental }\end{array}$ \\
\hline
\end{tabular}




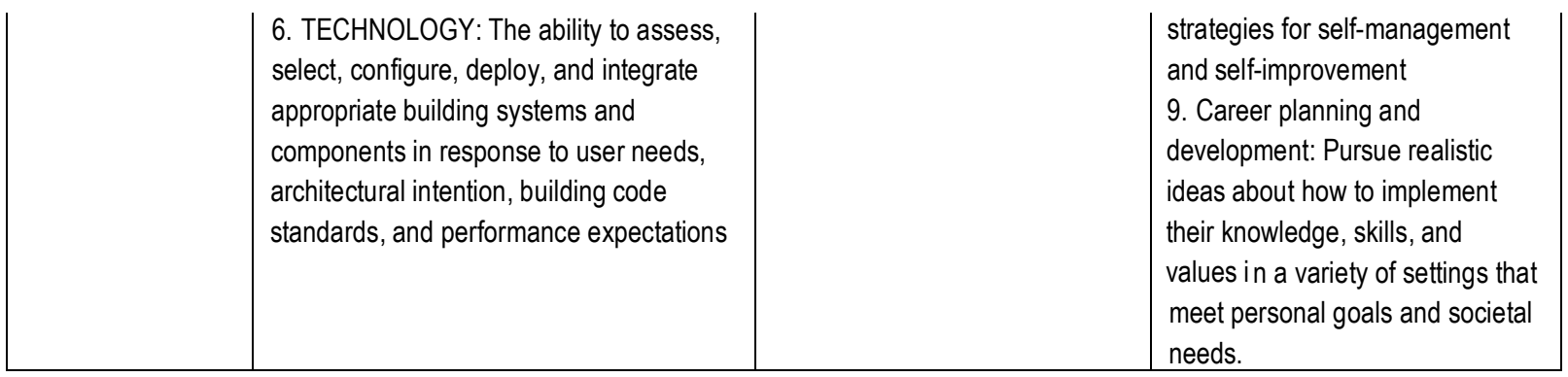

Table 6. Objectives

\begin{tabular}{|c|c|c|c|}
\hline $\begin{array}{l}\text { PLANNING } \\
\text { MODEL }\end{array}$ & CURRICULUM MODEL & NAAB & APA learning outcomes \\
\hline $\begin{array}{l}\text { Objectives- } \\
\text { checkpoints that } \\
\text { can be empirically } \\
\text { verified, what the } \\
\text { student is } \\
\text { expected to } \\
\text { demonstrate }\end{array}$ & $\begin{array}{l}\text { Authors' example of Quantitative } \\
\text { Environmental Systems course level } \\
\text { objectives: } \\
\text { Thermal topic learning objectives } \\
\text { 1) Analyze the characteristics and } \\
\text { passive design priorities of any climate at } \\
\text { the regional or city scale } \\
\text { 2) Evaluate and reconfigure the } \\
\text { aerodynamic, solar, and thermal } \\
\text { situations of a building site } \\
\text { 3) Design and evaluate shading devices } \\
\text { in terms of their seasonal performance } \\
\text { and response to building needs } \\
\text { 4) Understand the dynamic conditions of } \\
\text { thermal equilibrium in buildings } \\
\text { 5) Select and incorporate appropriate } \\
\text { envelope systems and evaluate their } \\
\text { expected performance } \\
\text { 6) Select, size and incorporate } \\
\text { appropriate passive heating systems and } \\
\text { evaluate their expected performance } \\
\text { 7) Select, size and incorporate } \\
\text { appropriate passive cooling systems and } \\
\text { evaluate their expected performance } \\
\text { 8) Provide for Indoor Air Quality in } \\
\text { building design } \\
\text { 9) Provide for moisture control in building } \\
\text { design (about } 33 \% \text { of the work an air } \\
\text { conditioner does) } \\
\text { 10) Incorporate thermal zoning as an } \\
\text { envelope and HVAC design determinate } \\
\text { (exposure, orientation, occupancy) }\end{array}$ & $\begin{array}{l}\text { Student Performance Criteria } \\
\text { for program learning } \\
\text { objectives (NAAB 2009) } \\
\text { 1. Ability to read, write, listen, } \\
\text { and speak effectively } \\
\text { 2. Ability to raise clear and } \\
\text { precise questions, use abstract } \\
\text { ideas to interpret information, } \\
\text { consider diverse points of view, } \\
\text { reach well-reasoned } \\
\text { conclusions, and test them } \\
\text { against relevant criteria and } \\
\text { standards } \\
\text { 3. Ability to use appropriate } \\
\text { representational media, } \\
\text { in cluding freehand drawing and } \\
\text { computer technology, to convey } \\
\text { essential formal elements at } \\
\text { each stage of the programming } \\
\text { and design process } \\
\text { 4. Ability to gather, assess, } \\
\text { record, and apply relevant } \\
\text { information in architectural } \\
\text { coursework. } \\
5 . \text { Understanding of the } \\
\text { fundamentals of visual } \\
\text { perception and the principles } \\
\text { and systems of order that } \\
\text { inform two- and three- } \\
\text { dimensional design, } \\
\text { architectural compo sition, and } \\
\text { urban design }\end{array}$ & $\begin{array}{l}\text { 1.1. Characterize the nature } \\
\text { of the discipline } \\
\text { 1.2. Demonstrate knowledge } \\
\text { and understanding } \\
\text { representing appropriate } \\
\text { breadth and depth of the } \\
\text { discipline } \\
\text { 1.3. Use the concepts, } \\
\text { language, and major theories } \\
\text { appropriately } \\
\text { 1.4. Explain major theories to } \\
\text { produce comprehensive and } \\
\text { multi-faceted explanations } \\
2.1 \text { Describe the basic } \\
\text { characteristics of the discipline } \\
\text { as a science } \\
2.2 \text { explain different resea rch } \\
\text { methods } \\
2.3 \text { evaluate the results and } \\
\text { conclusions derived from } \\
\text { research } \\
2.4 \text { Design and conduct basic } \\
\text { studies } \\
2.5 \text { Follow APA Code of Ethics } \\
\text { with regard to conducting } \\
\text { research with humans and } \\
\text { nonhumans } \\
2.6 \text { Generalize research } \\
\text { appropriately } \\
3.1 \text { Use critical thinking } \\
\text { effectively } \\
3.2 \text { Engage in critical thinking }\end{array}$ \\
\hline
\end{tabular}


11) Schematically select, size and incorporate appropriate HVAC systems and evaluate their expected performance 12) Physically and functionally integrate HVAC equipment and its hardware requirements into a building

13) Schematically size and incorporate appropriate HVAC delivery and

distribution systems

- Lighting topic learning objectives

1) Evaluate the daylighting resource of any given location accounting for seasonal and daily variation 2) Schematically size daylighting systems according to their desired annual performance

3) Resolve the seasonal performance of a daylighting system relative to solar heat gain and illumination levels

4) Select appropriate daylighting strategies, glazing types and system configurations

5) Select, size and incorporate appropriate daylighting systems and evaluate their expected performance 6) Incorporate luminous zoning as a design determinate (perimeter, interior, core, atrium...)

7) Understand photometric terminology and the qualitative properties of light sources

8) Estimate the power and energy consumption of electrical lighting systems for a given illumination level

9) Select, size and incorporate appropriate task lighting systems and evaluate their expected performance 10) Understand light loss factors and the differences between initial and maintained illumination

11) Select, size and incorporate appropriate ambient lighting systems and evaluate their expected performance Acoustics topic lear ning objectives 1) Understand the logarithmic measures of acoustical intensity and loudness 2) Select, size and incorporate appropriate room configurations and materials for sound quality

3) Design rooms to achieve desirable reverberation time
6. Ability to use basic architectural principles in the design of buildings, interior spaces, and sites

7. Ability to recognize the varied talent found in interdisciplinary design project teams in professional practice and work in collaboration with other students as members of a design team

8. Understanding of the Western architectural canons and traditions in architecture, landscape and urban design, as well as the climatic,

technological, socioeconomic, and other cultural factors that have shaped and sustained them

9. Understanding of parallel and divergent canons and traditions of archi tecture and urban design in the non-Western world

10. Understanding of national traditions and the local regional heritage in architecture, landscape design and urban design, including the vernacular tradition

11. Ability to incorporate

relevant precedents into architecture and urban design Projects

12. Understanding of the theories and methods of inquiry that seek to clarify the relationship between human behavior and the physical environment

13. Understanding of the diverse needs, values, behavioral norms, physical ability, and social and spatial patterns that characterize different cultures and individuals and the implication of this diversity for the societal roles and responsibilities of architects 14. Ability to design both site
3.3 Use reasoning to recognize, develop, defend and criticize arguments and other persuasive appeals 3.4 Approach problems effectively

4.1 Describe major applied areas of the discipline 4.2 Identify appropriate strategies to solve problems 4.3 Articulate how principles can be used to explain social issues and inform public policy 4.4 Apply concepts, theories and research findings to everyday life 4.5 Recognize ethically complex situations 5.1 Recognize the necessity of ethical behavior in all aspects of the science and practice 5.2 Demonstrate reasonable skepticism and intellectual curiosity by asking questions about causes of behavior 5.3 Seek and evaluate scientific evidence for findings and claims.

5.4 Tolerate ambiguity and recognize that psychological explanations are often complex 5.5 Recognize and respect human diversity 5.6 Assess and justify student engagement with respect to civic, social and global responsibilities

5.7 Understand the limitations of student knowledge and skills

6.1 Demonstrate information competence in formulating a research topic, search the databases, locating and selecting relevant sources from appropriate media 6.2 Use appropriate software to produce reports 6.3 Use information and technology ethically and 
4) Design rooms to achieve effective sound reflection and passive reinforcement

5) Design rooms to avoid acoustical defects

6) Incorporate acoustical zoning as a design determinate (noisy, quiet, silent, private, and buffer spaces)

7) Understand physical properties of room-to-room noise barriers for air borne and structure borne noise

8) Select appropriate Room Criteria background masking sound l evels in rooms

9) Select appropriate barrier ratings of sound Transmission Loss and Sound Transmission Class

10) Understand mechanical noise problems

11) Design and evaluate effective outdoor noise barriers and building to accommodate individuals with varying physical abilities

15. Understanding of the principles of sustainability in making architecture and urban design decisions that conserve natural and built resources, including culturally important buildings and sites, and in the creation of healthful buildings and communities

16. Ability to prepare a comprehensive program for an architectural project, including assessment of client and user needs, a critical review of appropriate precedents, an inventory of space and equipment requirements, an analysis of site conditions, a review of the relevant laws and standards and assessment of their implication for the project, and a definition of site selection and design assessment criteria 17. Ability to respond to natural and built site characteristics in the development of a program and the design of a project 18. Understanding of principles of structural behavior in withstanding gravity and lateral forces and the evolution, range, and appropriate application of contemporary structural systems

19. Understanding of the basic principles and appropriate application and performance of environmental systems, including acoustical, lighting, and climate modification systems, and energy use, integrated with the building envelope

20. Understanding of the basic principles of life-safety systems with an emphasis on egress responsibility

6.3 Demonstrate basic word processing skills, database, email, spreadsheet, and data analysis. Use the web and proper etiquette and security safeguard when communicating through email 7.1 Demonstrate effective writing and oral communication skills in various format and for various purposes 7.2 Exhibit quantitative literacy 7.3 Demonstrate effective interpersonal communication skills

7.4 Exhibit the ability to collaborate effectively 8.1 Interact effectively and sensitively with people of diverse abilities, backgrounds and cultural perspectives

8.2 Examine sociocultural and international contexts that influence individual differences 8.3 Explain how individual differences influence beliefs, values, and interactions with others and vice versa 8.4 Understand how privilege, power, and oppression may affect prejudice, discrimination, and inequity 8.5 Recognize prejudicial attitudes and discriminatory behaviors that might exist in themselves and in others 8.6 Predict how interaction among diverse people can challenge conventional understanding 9.1 Reflect on experiences and find meaning in them 9.2 Apply principles to promote personal development 9.3 Enact self-management strategies that maximize 
21. Understanding of the basic principles and appropriate application and performance of building envelope materials and assemblies

22. Understanding of the basic principles and appropriate application and performance of plumbing, electrical, vertical transportation, communication, security, and fire protection systems

23. Ability to assess, select, and conceptually integrate structural systems, b uilding envelope systems, environmental systems, life-safety systems, and building service systems into building design

24. Understanding of the basic principles and appropriate application and performance of construction materials, products, components, and assemblies, including their environmental impact and reuse 25. Understanding of the fundamentals of building cost, life-cycle cost, and construction estimating

26. Ability to make technically precise drawings and write outline specifications for a proposed design

27. Understanding of the responsibility of the architect to elicit, understand, and resolve the needs of the client, owner, and user

28. Ability to produce a comprehensive architectural project based on a building program and site that includes development of programmed spaces demonstrating an understanding of structural and environmental systems, building envelope systems, life-safety provisions, wall sections and building assemblies and the healthy outcomes

9.4 Display high standards of personal integrity with others 9.5 Seek input from and experiences with diverse people to enhance the quality of solutions 10.1 Apply knowledge of the discipline (e.g., decision strategies, psychological assessment, types of psychological careers) when formulating career choices 10.2 Identify the types of academic experience and performance in the dis cipline and the liberal arts that will facilitate entry into the workforce, post baccalaureate education, or both 10.3 Describe preferred career paths based on accurate selfassessment of abilities, achievement, motivation, and work habits

10.4 Identify and develop skills and experiences to achieving selected career goals 10.5 Articulate how changing societal needs can influence career opportuniti es and foster flexibility 10.6 Demonstrate an understanding of the importance of lifelong learning and personal flexibility to sustain personal and professional development as the nature of work evolves. 
principles of sustainability

29. Understanding of obtaining commissions and negotiating contracts, managing personnel and selecting consultants, recommending project delivery methods, and forms of service contracts

30. Understanding of the basic principles and legal aspects of practice organization, financial management, business planning, time and project management, risk mitigation, and mediation and arbitration as well as an understanding of trends that affect practice, such as globalization, outsourcing, project delivery, expanding practice settings, diversity, and others

31. Understanding of the role of internship in obtaining licensure and registration and the mutual rights and responsibilities of interns and employers

32. Understanding of the need for architects to provide leadershi $p$ in the building design and construction process and on issues of growth, development, and aesthetics in their communities 33. Understanding of the architect's responsibility as determined by registration law, building codes and regulations, professional service contracts, zoning and subdivision ordinances, environmental regulation, historic preservation laws, and accessibility laws 34. Understanding of the ethical issues involved in the formation of professional judgment in architectural design and practice. 
Table 7. Tactics and Strategies

\begin{tabular}{|c|c|c|c|}
\hline $\begin{array}{l}\text { PLANNING } \\
\text { MODEL }\end{array}$ & CURRICULUM MODEL & NAAB & APA \\
\hline $\begin{array}{l}\text { Tactics- activities } \\
\text { used to achieve } \\
\text { objectives in line } \\
\text { with goals and } \\
\text { mission }\end{array}$ & $\begin{array}{l}\text { Tactics are usually described at the } \\
\text { course level to specify student activities }\end{array}$ & Not prescribed & $\begin{array}{l}\text { 1. Objective test to measure } \\
\text { knowledge base } \\
\text { 2. Essay tests using a grading } \\
\text { rubric } \\
\text { 3. Embedded question and } \\
\text { assignments } \\
\text { 4. Classroom assessment } \\
\text { techniques (e.g., 1-minute } \\
\text { paper, free-writings) } \\
\text { 5. Term papers, lab reports, } \\
\text { criti ques } \\
\text { 6. Oral presentations } \\
\text { 7. Graphic test and displays } \\
\text { (concept maps, outlines) } \\
\text { 8. Posters } \\
\text { 9. Capstone experience } \\
\text { 10. Internship } \\
\text { 11. Portfolios } \\
\text { 12. Research teams and } \\
\text { group projects } \\
\text { 13. Online activities } \\
\text { 14. Surveys (satisfaction, } \\
\text { perceptions) } \\
\text { 15. Exit interviews } \\
\text { 16. Focus groups } \\
\text { 17. Follow-up alumni } \\
\text { interviews } \\
\text { 18. External examiners }\end{array}$ \\
\hline $\begin{array}{l}\text { Strategy- plan for } \\
\text { how it all comes } \\
\text { together with } \\
\text { timing, resources, } \\
\text { and } \\
\text { responsibilities }\end{array}$ & $\begin{array}{l}\text { Individually based due to range of } \\
\text { resources }\end{array}$ & Not prescribed & Not prescribed \\
\hline
\end{tabular}




\section{Alignment and coordination of learning outcomes within an architectural education curricula}

Follow-up activities must be encouraged to develop learning outcomes. For instance, a specific set of actions should set the development of relevant grading rubrics and exemplars of different evaluation tools that can be used both in lecture and studio. Workshops can be organized to present ideas to help faculty members integrate specific learning outcomes within their syllabi and properly assess and report learning outcomes. Another strategy used in ongoing assessment of architecture education is to require a capstone course in which student exercise the full range of program learning outcomes. Grading rubrics can also be developed to examine students' learning.

A rubric is an assessment tool used to measure students' work and serves as a scoring guide to evaluate a student's performance based on the sum of a full range of criteria rather than a single numerical score. A rubric is a working guide for students and teachers, usually handed out before the assignment begins to let students know the criteria on which their work is evaluated. Rubrics can be analytic or holistic, and they can be created for any content area including architecture. When a rubric becomes an ongoing part of the teaching and learning process, students are involved in the assessment process through both peer and selfassessment. As students become familiar with rubrics, they can assist in the rubric design process. This involvement empowers the students and as a result, their learning becomes more focused and self-directed (Pickett and Dodge, 2001). Using a rubric has several advantages

- allow assessment to be objective and consistent

- help to state criteria in specific terms

- clearly show the student how their work is evaluated and what is expected

- provide useful feedback regarding the effectiveness of the instruction

- provide standard against which to measure and document progress

Rubrics can be created in a variety of forms and levels of complexity; yet, they include common features. Rubrics

- measure a stated objective (performance, behavior, or quality) using a specific range to rate performance, and

- contain specific performance characteristics arranged in levels indicating the degree to which a standard has been met (see example in Table 8).

\section{Table 8: Example of a Rubric}

\begin{tabular}{|l|l|l|l|l|l|}
\hline $\begin{array}{l}\text { Criteria } \\
\text { This assignment: }\end{array}$ & Excellent & Very good & Adequate & Weak & Poor \\
\hline Responds fully to the assignment & & & & & \\
\hline Identifies issue and position & & & & & \\
\hline Exercise good critical thinking & & & & & \\
\hline $\begin{array}{l}\text { Expresses its purpose clearly and } \\
\text { persuasively throughout }\end{array}$ & & & & & \\
\hline $\begin{array}{l}\text { Invokes and uses the discipline } \\
\text { concepts correctly }\end{array}$ & & & & & \\
\hline $\begin{array}{l}\text { Provides adequate supporting } \\
\text { argument, evidence and examples }\end{array}$ & & & & & \\
\hline $\begin{array}{l}\text { Is focused, well organized and } \\
\text { unified }\end{array}$ & & & & & \\
\hline $\begin{array}{l}\text { Uses language that is appropriate } \\
\text { for the audience }\end{array}$ & & & & & \\
\hline $\begin{array}{l}\text { Correctly documents and cites } \\
\text { sources }\end{array}$ & & & & & \\
\hline $\begin{array}{l}\text { Is free of errors in grammar, } \\
\text { punctuation, word choice, spelling } \\
\text { and format }\end{array}$ & & & & & \\
\hline Displays originality and creativity. & & & & & \\
\hline Overall evaluation & & & & & \\
\hline
\end{tabular}




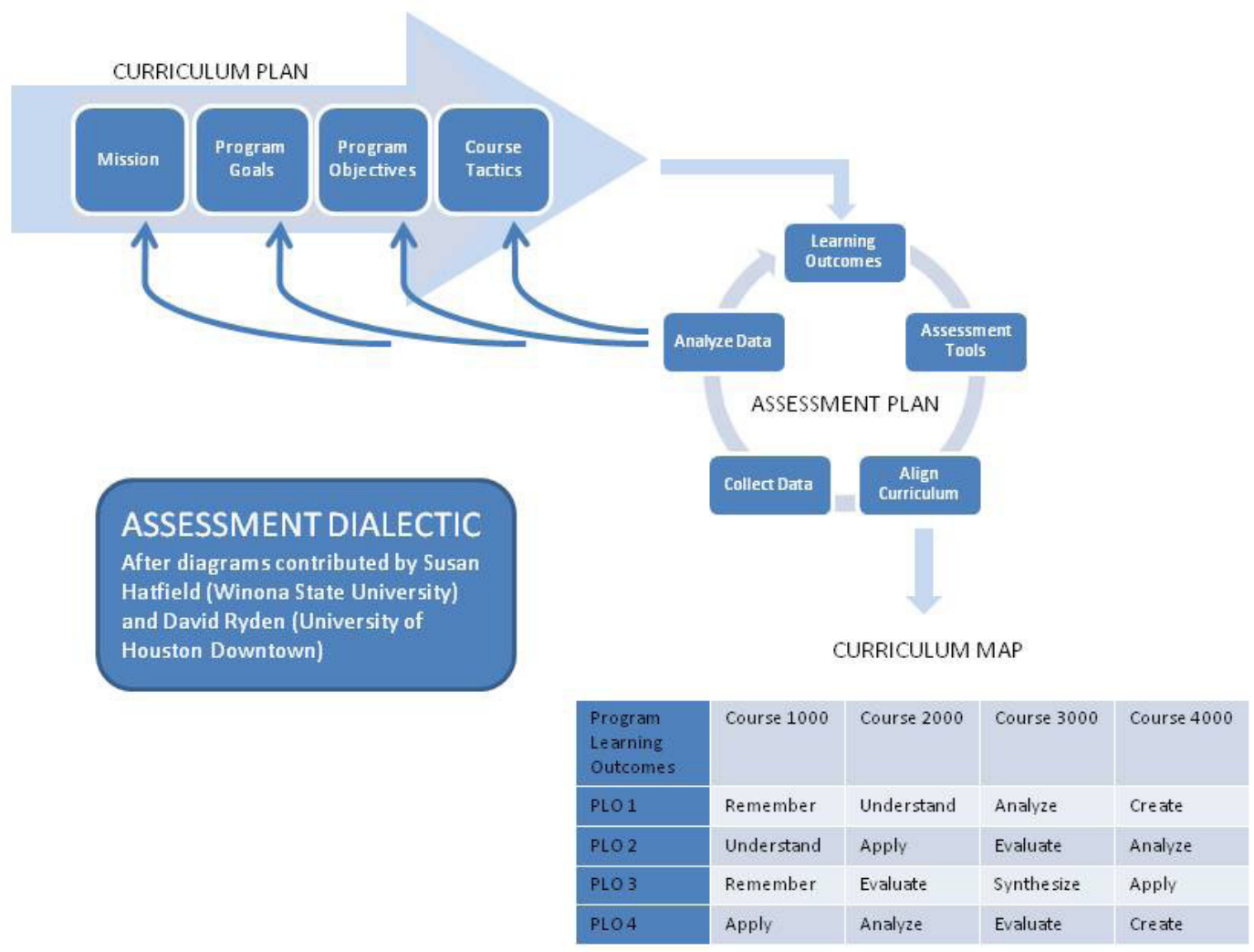

Figure 3: Overview of curriculum plan, assessment plan, curriculum map, and program learning outcomes.

Other follow-up activities include indirect measure of students' perception of their learning. Asking students to comment on their performance and their level of preparation to perform within each area can be accomplished via a survey, a discussion group or exit interview. Using such measure allows the program to measure weak areas of learning, to reflect on improving those weak areas, to identify creative ways to improve student learning.

\section{Discussion}

Changes in educational assessment are called for in every academic discipline. The emerging vision of continuous assessment includes a dynamic process that yields information about student progress toward achieving a set of learning goals. Figure 3 summarizes the various aspects covered in this paper and illustrates how the learning outcomes are used in the assessment process which in turn is used in evaluating the curriculum map and making appropriate changes in the program.
As architecture schools develop and refine meaningful learning outcomes in this new culture of evidence, we invite NAAB and all concerned to continue providing a framework for measurement and assessment that is increasingly well operationalized and reliable. Having such a model available would assist architectural institutions and faculty to develop, implement, assess and thereby improve curricula. Some models of student learning are already available in other disciplines. The AAC\&U's Liberal Education and America's Promise (LEAP) initiative, for example, were launched in 2005 to identify essential learning outcomes for all undergraduates. The LEAP goals are to promote a wide-ranging education for individual students and ensure competiveness at national and global levels. We should aspire and plan for nothing less in architectural education. 


\section{Bibliography}

ACSA Report for the Accreditation Review Conference: A report. Retrieved on 12/1/08 from www.naab.org/documents/streamfile. aspx?name=ACSA--ARC-Report-Feb-2008. pdf\&path=Public+Documen ts $\% 5$ CAccreditation $\% 5 C$

American Institute of Architects. Learning objectives: What are they and how do I write one? Retrieved on 3/5/09 from http://www.aia.org/ education/providers/AIAS076145

American Psychological Association. 2008. Undergraduate psychology major learning goals and outcomes: A report. Retrieved on 12/1/08 from http://www.apa.org/ed/pcue/taskforcereport.pdf

Anderson, Lorin W. and David R. Krathwohl. 2001. A Taxonomy for learning, teaching and assessing: A revision of Bloom's Taxonomy of Educational Objectives. New York: Longman

Angelo, Tom D. 1995. Reassessing (and defining) assessment. The AAHE Bulletin, 48(2), 7-9.

Bailey, Kenneth. 1994. Methods of social research (4th ed.) New York: The Free Press, 504

Banta, Trudy. 2007. A warning on measuring learning outcomes. Inside Higher Ed. Retrieved on 3/15/09 from http://www.insidehighered.com/ views/2007/01/26/banta

Bloom, Benjamin. 1956. Taxonomy of educational objectives: The classification of educational goals. Handbook . New York: Longmans, Green.

Boyer, Ernest L. and Mitgang, Lee D.1996. Building community: A new future for architecture education and practice. Princeton, NJ: The Carnegie Foundation for the Advancement of Teaching.

Bresciani, Marilee J. 2001. Writing measurable and meaningful outcomes. NetResults. Retrieved 4/25/09 from http://www.ncsu.edu/ assessment/evaluation/writingoutcomes.pdf

Bresciani, Marilee J. 2007. Frameworks for assessing learning and development. Journal of College Student Development, 48(5), 616-618 Bresciani, Marilee J., Carrie L. Zelna and James A. Anderson. 2004. Assessing student learning and development: A handbook for practitioners. Washington, D.C.: NASPA.

Carnegie Academy for the Scholarship of Teaching and Learning. Retrieved on 4/15/09 from http://www.carnegiefoundation.org/programs/ index.asp?key=21 and http://academics.georgiasouthern.edu/ijsot// conference/2009/index.htm

Coleridge, Samuel Taylor. 1956. Biographia Literaria: Or, Biographical Sketches of My Literary Life and Opinions. New ed. London: J. M. Dent. Dickhut, Johanna E. (n.d.) A brief review of creativity. Retrieved on 1/24/09 from http://www.personalityresearch.org/papers/dickhut.html

Eder, Douglas J. 2004. General education assessment within the disciplines. JGE: The Journal of General Education, 53(2), 135.

Erwin, T. Dary. 1991. Assessing student learning and development: A guide to the principles, goals, and methods of determining college outcomes. San Francisco: Jossey-Bass

Finke, Ronald A., Thomas B. Ward and Steve M. Smith. 1996. Creative cognition: Theory, Research and Applications. The MIT Press

Greenspan, Deborah A., Rebecca Solomon and Howard Gardner. 2005. The development of talent in different domains. In L. V. Shavinina and M. Ferrari. Eds. Beyond knowledge: Extracognitive aspects of developing high ability. Mahwah, N.J.:Lawrence Erlbaum Associates, Publishers, 119. Harden, R. M. 2001. AMEE Guide No. 21: Curriculum mapping: a tool for transparent and authentic teaching and learning. Medical Teacher, 23(2), 123-137.

Hart, Peter D. 2008. How should colleges assess and improve student learning? http://www.aacu.org/LEAP/documents/2008_Business_ Leader_Poll.pdf

Heath, Tom. 1991. What, if anything, is an architect? Melbourne: Architecture Media Australia.

Howe, Michael J. 2005. Some insights of geniuses into the causes of exceptional achievement. In L. V. Shavinina and M. Ferrari. Eds. Beyond knowledge: Extracognitive aspects of developing high ability. Mahwah, N.J.: Lawrence Erlbaum Associates, Publishers, 103

Hutchins, Pat, Marcia Babb and Chris Bjork. 2002. The scholarship of teaching and learning in higher education: An annotated bibliography. The Carnegie Academy for the Scholarship of Teaching and Learning. Retrieved on 12/1/08 from http://www.carnegiefoundation.org/dynamic/ downloads/file_1_196.pdf

Kahn, Louis, 1961. Form and Design, Architectural Design, 149.

Leskes, Andrea 2002. Beyond confusion: an assessment glossary. Peer Review, 4(2/3).

Mayo, James M. 1991. Dilemmas of architectural education in the academic political economy. In Voices in architectural education: Cultural politics and pedagogy. T. A. Dutton. Ed. New York: Bergin and Garvey, 65 NAAB. 2008. Fusion model discussion draft No. 2. 2008. Accreditation Review Conference. Retrieved on 12/1/08 from http://www.naab.org/ documents/home_origin.aspx?path=Public+Documents $\backslash$ Accreditation NAAB. 2009. Accreditation review conference. Proposed NAAB Accreditation Model (2009-2015). Retrieved on 3/10/09 from https:// www.acsa-arch.org/files/about/Fusion\%20Model\%20Discussion\%20 Draft\%201.pdf

NAAB. 2009. Conditions for Accreditation, Public Comment Edition as of 2/27/09. Retrieved on 3/19/09 from http://www.naab.org/documents/ streamfile.aspx?name $=2009+$ Conditions+Edition+for+Public+Comment. pdf\&path=Public+Documents $\% 5 c$

National Center for Research and Evaluation, Standards \& Student Testing (CRESST). Glossary. Retrieved on 3-15-09 from http://www. bmcc.cuny.edu/genedassess/Glossary.html

Oklahoma State University--School of Architecture. 2004. Outcome assessment plan. Retrieved on 12/1/08 from http://accreditation.okstate. edu/RR/assessment/plans/ceat/architecture.pdf

Petri, Elizabeth. 2004. Work in progress, education and practice: Assessment for architecture education. Frontiers in Education, 3, S3G/13- S3G/14. Retrieved on 3/15/09 from http://fie-conference.org/ fie2004/papers/1304.pdf 
Pickett, Nancy and Bernie Dodge. 2001. Rubrics for Web Lessons. Retrieved on 3/15/09 from http://edweb.sdsu.edu/webquest/rubrics/ weblessons.htm

Radcliff, James L., Edward Lubinescu, and Maureen A. Gaffney. 2001. How accreditation influences assessment: New directions for higher education, No. 113. New York: Jossey-Bass.

Rogers, Gloria. 2009. Using assessment to drive improvement without driving faculty crazy. Texas A\&M Assessment Conference. Retrieved on 3/5/09 from http://assessment.tamu.edu/conference/handouts_2009/ Rogers_Plenary_Assessment4lmprovement.pdf

Shavinina, Larisa V. and Michael Ferrari. 2004. Extracognitive facets of developing high ability: Introduction to some important issues. In L. V. Shavinina and M. Ferrari. Eds. Beyond knowledge: Extracognitive aspects of developing high ability. Mahwah, N.J.: Lawrence Erlbaum Associates, Publishers, 3-12

Shulman, Dina. 2007. Counting and recounting: Assessment and the quest for accountability. Change. Retrieved on 3/15/09 from http://www. carnegiefoundation.org/perspectives/index.asp?key $=532$

Southern University School of Architecture. Program learning outcomes. Retrieved on 12/1/08 from http://www.subr.edu/programmapping/pdfs/ archioutcome.pdf

Spiridonidis, Constantin. Aristotle. nd. Creating competences based architectural curricula for transparency, quality and mobility. Retrieved on 12/1/08 from http://ec.europa.eu/education/programmes/mundus/ projects/action4/08enhsa.pdf

Sternberg, Robert J. 2006. The nature of creativity. Creativity Research Journal, 18(1), 897-98.

Subotnick, Rena F. 2005. Transforming elite musicians into professional artists: A view of the talent development process at the Juillard School. In L. V. Shavinina and M. Ferrari (Eds.). Beyond knowledge: Extracognitive aspects of developing high ability. Mahwah, N.J.: Lawrence Erlbaum Associates, Publishers, 137.

Texas A\&M. 2009. Assessment Conference. Retrieved on 3/5/09 from http://assessment.tamu.edu/conference/handouts_2009/Rogers_ Plenary_Assessment4Improvement.pdf

Trochim, William K. 2000. The research methods knowledge base (2nd ed.). Atomic Dog Publishing, Cincinnati, $\mathrm{OH}$.

University of Western Australia. nd. Architecture Assessment. Retrieved on 12/1/08 from http://www.alva.uwa.edu.au/staffnet/teaching/arch_ assess

Watt, Kathleen and Derek Cottrel. 2006. Grounding the curriculum: Learning from live projects in architectural education. International Journal of Learning, 13(8), 97-104

Millersville University Assessment and planning. Why do we do outcome assessment. Assessment Glossary. Retrieved on 3/10/09 from http:/l www.millersville.edu/ assessmt/why.html?menu=Why 